Jurnal mandiri IT

Vol. 10 No. 1, July (2021), pp. 29-33
ISSN 2301-8984 (Print), 2809-1884 (Online)

Published by Institute of Computer Science

\title{
First Aid Application Development Android Smartphone
}

\author{
Imamul Huda \\ Informatics Engineering Study prigram, Facultas of Science And Technology \\ Universitas Islam Negeri Syarif Hidayatullah Jakarta
}

\begin{abstract}
ARTICLEINFO
Article history:

Received Jun 19, 2021

Revised Jul 01, 2021

Accepted Jul 21, 2021

\section{Keywords:}

Smartphones;

First Aid Tutorials;

Androids;

Froyo.

ABSTRACT

Rapid technological advances have turned mobile mobile devices into smartphones that have various applications in them. So that the smartphone device becomes the main need for its users. Several new breakthroughs can be present on smartphones such as applications around health. Where accidents can happen to anyone, anywhere and anytime. First aid measures are very important to do to reduce the impact of accidents. So the researchers developed an Accident First Aid (P3K) application on the Android platform with version 2.2 Froyo. The first aid application has a main feature that contains tutorials on first aid measures in an accident, as well as several additional features in the form of drug information, information on the location of the nearest hospital and pharmacy, types of rescue techniques, and emergency number calls. By using the Rapid Application Development system development methodology which consists of three phases, namely planning, design and implementation of the workshop, this application is made using the Android SDK Framework, Java Programming Language, googlemaps as a spatial data service and system testing has been carried out using the Black Box testing method. . This application, which has a file memory of $3.5 \mathrm{Mb}$, can help smartphone users to recognize, learn and understand various first aid measures and become an application that can help victims when an accident occurs. googlemaps as a spatial data service and system testing has been carried out using the Black Box testing method. This application, which has a file memory of $3.5 \mathrm{Mb}$, can help smartphone users to recognize, learn and understand various first aid measures and become an application that can help victims when an accident occurs. googlemaps as a spatial data service and system testing has been carried out using the Black Box testing method. This application, which has a file memory of $3.5 \mathrm{Mb}$, can help smartphone users to recognize, learn and understand various first aid measures and become an application that can help victims when an accident occurs.
\end{abstract}

This is an open access article under the CC BY-NC license.

\section{Corresponding Author:}

Imamul Huda,

Informatics Engineering Study prigram, Facultas of Science And Technology

Universitas Islam Negeri Syarif Hidayatullah Jakarta

E-mail: imanuelhuda76@gmail.com

\section{INTRODUCTION}

Currently, there are many smartphone technologies that are already popular among the public, such as iPhone and Android. Android is a piece of software for mobile devices that includes an operating system, middleware and core applications released by Google. Android is also able to 
integrate with various Google services such as Googlemaps, in displaying location information on a visual map. Meanwhile, the Android SDK (Software Development Kit) provides the tools and APIs needed to develop applications on the Android platform using the Java programming language. Android was developed with the spirit of open source and makes it easier for developers to increase creativity in developing applications in it (Mulyadi, 2010).

Various community activities have resulted in an increase in the number of accidents that occur in Indonesia, both work accidents and traffic accidents, resulting in many victims. This can be seen from the amount of data obtained from the Central Statistics Agency which shows the number of accidents is getting higher from year to year. For this reason, it is important to have a first aid kit as a solution in reducing the adverse effects that occur due to accidents. P3K (First Aid in Accident) contains maintenance techniques along with a set of supporting tools that can assist in dealing with accidents and minimizing the further impact of accidents. However, the importance of first aid is not accompanied by sufficient knowledge in the community in its application. Because all this time, First aid knowledge is only obtained from books, school extracurriculars and health education. Then added data from the questionnaire results given to 40 respondents who are also potential first aid users, which shows that $90 \%$ of respondents do not know about first aid measures. This is also consistent with the results of interviews with informants who stated that there was still a lack of public knowledge about first aid measures. In addition, as many as $92 \%$ of respondents stated the need for other alternatives as a medium to provide knowledge about First Aid where in this context the researcher proposes an Android smartphone mobile application as an alternative media solution. Then added data from the questionnaire results given to 40 respondents who are also potential first aid users, which shows that $90 \%$ of respondents do not know about first aid measures. This is also consistent with the results of interviews with informants who stated that there was still a lack of public knowledge about first aid measures. In addition, as many as $92 \%$ of respondents stated the need for other alternatives as a medium to provide knowledge about First Aid where in this context the researcher proposes an Android smartphone mobile application as an alternative media solution. Then added data from the questionnaire results given to 40 respondents who are also potential first aid users, which shows that $90 \%$ of respondents do not know about first aid measures. This is also consistent with the results of interviews with informants who stated that there was still a lack of public knowledge about first aid measures. In addition, as many as $92 \%$ of respondents stated the need for other alternatives as a medium to provide knowledge about First Aid where in this context the researcher proposes an Android smartphone mobile application as an alternative media solution. This is also consistent with the results of interviews with informants who stated that there was still a lack of public knowledge about first aid measures. In addition, as many as $92 \%$ of respondents stated the need for other alternatives as a medium to provide knowledge about First Aid where in this context the researcher proposes an Android smartphone mobile application as an alternative media solution. This is also consistent with the results of interviews with informants who stated that there was still a lack of public knowledge about first aid measures. In addition, as many as $92 \%$ of respondents stated the need for other alternatives as a medium to provide knowledge about First Aid where in this context the researcher proposes an Android smartphone mobile application as an alternative media solution.

Based on this background, researchers are motivated to develop an Android smartphonebased application for first aid action guidance, this application will be able to display first aid actions in dealing with accidents ranging from information about preventive measures, information about medicines, the location of the nearest hospital and pharmacy. from the user's position, emergency calls to agencies that can assist in dealing with accidents and are able to display video guidance in dealing with accidents. Based on this background, a research was conducted with the title "Development of an Android Smartphone-Based First Aid Application".

\section{METHOD}

1. Method of collecting data

Data collection is nothing but the process of procuring primary data for research purposes. According to Moh. Nazir (2005) data collection is a systematic and standard procedure to 
obtain the required data. In this study, the researcher used three ways to collect data, namely observation, interviews, and similar literature studies.

2. Research methods

The system development method used by the researcher in this research is the Rapid Application Development (RAD) method introduced by James Martin in 1991. RAD is a development cycle designed to provide much faster development and high-quality results than is achieved with a traditional life cycle. . (SHPS). This method was chosen because the system is expected to have a design that is acceptable to consumers and can be developed easily because the current system design still requires further development. Another reason for choosing this method is the existence of system limitations which are necessary for the system to not change. In addition, Rapid Application Development (RAD) was chosen because the application to be built is an application that was built in a fairly short time.

3. Field Study

In the field study data collection method, the researcher distinguishes it into three parts, namely observationData collection by direct observation or by direct observation is a way of collecting data using the eyes without the help of other standard tools for this purpose. (Nazir, 2005, Interview or interview is the process of obtaining information for research purposes by means of question and answer, while face to face between the questioner or interviewer and the answerer or respondent. Questionnaire To find out the problems and desires expected by prospective users of the application, the distribution is carried out questionnaires to respondents who will be used as data samples. The sample taken is 40 , the researcher divides it into two parts, namely 15 respondents who already know about P3K for this case, namely students of the Faculty of Medicine, UIN Syarif Hidayatullah Jakarta.

\section{RESULTS AND DISCUSSIONS}

1. Planning Terms

As described in the previous chapter, this phase is the phase where the researcher identifies the objectives of the application or system and identifies the information requirements that arise from these goals.

a. Tu System prototype development aims to help android users in providing first aid in the event of an accident whether it happens to themselves or others.

b. Looking for Information About First Aid

The purpose of searching for First Aid Information aims to fulfill the completeness of the data for the first aid handling actions. Here, the researcher searches for first aid information through books that discuss first aid, interviews with people who understand first aid, and searches for information on a special website about first aid (first aid).

c. Studying Android Smartphone User Culture

The purpose of studying the culture of Android smartphone users is to find out the habits of Android smartphone users when interacting with applications and to maximize the design of the user interface or application interface that will be developed.

d. Analyzing Some Applications About First Aid

The researcher conducted an analysis on a number of Android applications about first aid with different media platforms, the aim was to get an initial picture of the features, user interface and functionality to make it easier for researchers to make innovations in the applications to be developed.

e. Identifying Application Features

researchers identify features based on application or system goals and identify information requirements that arise from these goals. In this phase, researchers also discussed with competent sources in the first aid field and also involved users of Android smartphones to provide input for applications to be developed. 
f. System Prototype Requirements

1The application is able to provide first aid information (P3K) to anyone, anywhere and anytime. The display presented is made user friendly, making it easier for users to use the existing features and understand the material contained in the application.

2. discussion

The first aid application developed has a display on the main menu consisting of 6 buttons, namely the first aid action button, drugs, hospital location info, pharmacy location info, rescue techniques, and emergency calls. Looks like in picture 1

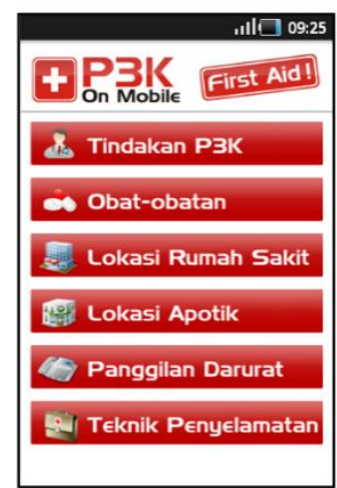

Figure 1. Main Menu Display

3. Alpha Test Results

Based on the results of testing with sample test cases that have been carried out, it can be concluded that functionally the system can produce the expected output. Beth testing is a test that is carried out objectively where the test is carried out directly in the field, namely the wider community and is not limited to certain circles. This test is carried out by making a questionnaire to find out respondents' opinions about the First Aid On Mobile application, and then distributed to several users to fill out which will later be used as samples and calculations to be carried out to draw conclusions on the results of making this expert system application.

Table 1.

Questionnaire Table

\begin{tabular}{|c|c|c|}
\hline No & Researched Points & $\begin{array}{l}\text { Percentage } \\
\text { Formula Used }\end{array}$ \\
\hline 1. & $\begin{array}{l}\text { Does the display of this expert system application look } \\
\text { attractive? }\end{array}$ & $Y=P / Q * 100 \%$ \\
\hline 2. & $\begin{array}{l}\text { Are the first aid apps easy to use? } \\
\text { Does the first aid application created provide the } \\
\text { necessary medical information? }\end{array}$ & \multirow{3}{*}{$\begin{array}{l}\text { Information: } \\
P=\text { Number of respondents' } \\
\text { answers to each question. } \\
Q=\text { Number of respondents } \\
Y=\text { Percentage value }\end{array}$} \\
\hline 4. & Are first aid apps made easy to learn? & \\
\hline 5. & Are expert system applications made useful? & \\
\hline
\end{tabular}

4. Beta Test Results

From the tests that have been carried out, namely by testing the calculation of the choice of answer categories from the questionnaires that have been distributed in the field, it can be concluded that this Android Smartphone-based First Aid Application looks attractive, easy to use, provides information, is easy to learn and is useful for users. 


\section{CONCLUSION}

From the discussion that has been explained, it can be concluded that the first aid application is an android smartphone application developed based on the rules of first aid medical action as a knowledge base. The first aid application is able to provide information about first aid measures along with supporting information, namely information about medicines, locations of hospitals and pharmacies, emergency numbers and rescue techniques needed to perform first aid measures.

\section{References}

Munawar. 2005. Pemodelan Visual dengan UML. Graha IImu. Murphy, Mark. 2009. Begining Android 2. APRESS: Barkeley.

Murphy, Mark. 2008. The Busy Coder's Guide To Android Development. CommonsWare: United States Of America.

Peraturan Mentri Tenaga Kerja dan Transmigrasi (Permenakertrans) Nomor : PER.15/MEN/VIII/2008 tentang Pertolongan Pertama pada Kecelakaan di Tempat Kerja.

Saubers, Nadine. 2011. Semua Yang Harus Anda Ketahui Tentang P3K. PallMall: Yogyakarta.

Siregar, Ivan Michael. 2010. Membongkar Source Code Berbagai Aplikasi ANDROID. Gava Media: Yogyakarta.

ST, Mulyadi. 2010. Membuat Aplikasi Untuk Android. Multimedia center Publishing: Yogyakarta.

Steele, James. 2010. The Android Developer's Cookbook: Building Applications with the Android SDK. Addison Wesley: New York.

Sudirman, Sulistro. 2008. Panduan P3K. Restu Agung: Jakarta. Sugiyono. 2005. Statistik Untuk Penelitian. Alfabeta: Bandung.

Thygerson, Alton. 2011. First Aid : Pertolongan Pertama Edisi Kelima. Erlangga: Jakarta

Undang-undang Ristek No. 18 Tahun 2002 Tentang Sistem Nasional Penelitian, Pengembangan, dan Penerapan IImu Pengetahuan dan Teknologi.

Yunisa, Ade. 2010. Pertolongan Pertama Pada Kecelakaan. Victory Inti Cipta: Jakarta.

Yusuf, Ronald. 2010. Aplikasi Enterprise Berbasis Android. Gava Media : Yogyakarta.

Zheing, Pei dan Ni, Lionel. 2006. Smartphone \& Next Generation Mobile Computing. Morgan Kaufman: San Fransisco. 